\title{
BASES DE DATOS POLICIALES SOBRE IDENTIFICADORES OBTENIDOS A PARTIR DEL ADN Y DERECHO A LA INTIMIDAD GENÉTICA*
}

\author{
Viviana CARUSO FonTÁN \\ Profesora Contratada Doctora \\ Universidad Pablo de Olavide \\ vcaruso@upo.es
}

\begin{abstract}
RESUMEN
La utilización de análisis de ADN como prueba pericial en el proceso penal y la posterior incorporación de esta información en bases de datos genéticas afectan tanto al derecho a la intimidad como al derecho a la autodeterminación informativa. En el presente trabajo se analizarán los requisitos que deberán reunir estas prácticas para que la conculcación de estos derechos fundamentales sea considerada proporcionada a los fines perseguidos y, por tanto, legítima desde un punto de vista constitucional.
\end{abstract}

Palabras clave: intimidad genética, autodeterminación informativa, base de datos, perfil de $\mathrm{ADN}$, sospechosos, condenados, delitos graves.

\section{ABSTRACT}

The use of DNA analysis as expert evidence in a criminal trial and the later incorporation of this information into genetic databases affect both the right to privacy and the right to informational self-determination. In the present work the requirements that these practices must have so that the violation of these fundamental rights is considered proportional to the purposes being pursued and, therefore, legitimate from the constitutional point of view, will be analyzed.

Keywords: genetic privacy, informational self-determination, database, DNA profile, suspects, convicts, serious crimes.

\section{ZUSAMMENFASSUNG}

Die Verwendung der DNA-Analyse als gerichtliches Beweismittel im Strafprozess und die anschließende Aufnabme dieser Daten in genetische Datenbanken

* El presente trabajo ha sido elaborado en el marco del Proyecto de Investigación de Excelencia de la Junta de Andalucía «La protección jurídica de la intimidad frente a las nuevas tecnologías de la información y la comunicación. Un análisis multidisciplinar», P10-SEJ-6735. 
berühren sowohl das Recht auf Privatsphäre als auch das Recht auf informationelle Selbstbestimmung. In der vorliegenen Arbeit werden die Vorbedingungen untersucht, die diese Praktiken erfüllen sollten, damit die Verletzung dieser Grundrechte als verbältnismässig zu den verfolgten Zwecken angesehen und folglich vom verfassungsrechtlichen Standpunkt aus als legitim betrachtet werden kann.

Schlüsselwörter: genetische Privatsphäre, Informationelle Selbstbestimmung, Datenbank, DNA-Profil, Verdächtige, Verurteilte, schwere Straftaten.

SUMARIO: I. SOBRE EL CONCEPTO DE INTIMIDAD.-1. La intimidad frente al derecho a la autodeterminación informativa.-2. La intimidad genética.II. BASES DE DATOS DE ADN. TERMINOLOGÍA.-III. LA UTILIZACIÓN DE MUESTRAS DE ADN EN LA PRÁCTICA FORENSE.-1. La obtención de muestras.-2. La realización de los análisis genéticos.-3. Incorporación de la información genética a la base de datos de perfiles de ADN.-IV. CONCLUSIONES.

\section{SOBRE EL CONCEPTO DE INTIMIDAD}

El imparable avance de la ciencia conlleva indudables beneficios para la humanidad. No obstante, junto a las numerosas aportaciones que proporcionan al ser humano, los avances científicos también engendran nuevos riesgos para los derechos individuales y ocasiones para la realización de hechos ilícitos. En este sentido, los estudios que en una época muy reciente han desvelado la información que el ser humano puede obtener a partir del ADN crean fundadas expectativas acerca de la posibilidad de prevenir numerosas enfermedades, además de brindar a la sociedad un instrumento de identificación de personas con probada eficacia. A pesar de ello, y en la medida en que esta información también puede ser utilizada de forma indebida, surge la necesidad de acuñar un nuevo derecho, el de «intimidad genética», como manifestación concreta del genérico derecho a la intimidad, el cual permita establecer el límite de la utilización legítima de dicha información. En el presente trabajo nos proponemos analizar el contenido y alcance del derecho a la intimidad genética como paso previo para poder constatar si este derecho puede verse afectado por la creación y desarrollo de bases de datos policiales de perfiles de ADN destinadas a la investigación criminal. 


\section{La intimidad frente al derecho a la autodeterminación informativa}

El derecho a la intimidad es recogido por primera vez en un texto constitucional español en 1978. El art. 18.1 de la Constitución Española sostiene que: «Se garantiza el derecho al honor, a la intimidad personal y familiar y a la propia imagen». La redacción de este precepto, donde se menciona de forma conjunta a estos tres conceptos, planteó dudas acerca de la configuración del derecho a la intimidad como un derecho único. No obstante, hoy en día de forma mayoritaria se afirma la plena autonomía del derecho a la intimidad personal ${ }^{1}$.

Es posible afirmar que el derecho a la intimidad como derecho subjetivo de la personalidad fue concebido originariamente como un derecho de defensa que se manifestaba en la posibilidad de negar a terceros el conocimiento de las propias experiencias personales ${ }^{2}$. Se caracterizaba así como el derecho a «ser dejado en paz» ${ }^{3}$. Su ámbito de aplicación correspondía exclusivamente a la esfera de los datos «íntimos», es decir, a la información confidencial que el sujeto quiere ocultar a la curiosidad ajena. Lo íntimo se opone a lo público y se relaciona con la soledad o con lo restringido y lo reservado; en definitiva, con aquel núcleo de relaciones que el titular del derecho selecciona sin dar acceso a nadie más que a quien él y sólo él permita $^{4}$. El concepto de intimidad tendrá, por tanto, un contenido más acotado que el término «privacidad», que se identifica con la figura anglosajona denominada «privacy» y que viene referida a datos o informaciones no íntimos, pero que el individuo desea que sólo sean conocidos por determinadas personas, queriendo sustraer su conocimiento a núcleos más amplios de la sociedad 5 .

1 Vid. C. Ruiz Miguel, La configuración constitucional del derecho a la intimidad, Madrid, 1995 , pp. 76 y ss.

${ }^{2}$ Las características del derecho a la intimidad que determinan su cualidad de derecho subjetivo de la personalidad son la esencialidad, la inherencia a la persona y la extrapatrimonialidad. Al respecto A. I. HerRán OrTiz, El derecho a la intimidad en la nueva Ley Orgánica de Protección de Datos Personales, Sevilla, 2002, p. 32.

3 Sobre el concepto de intimidad como el «derecho a ser dejado en paz», vid. F. RuIz MARCO, Los delitos contra la intimidad. Especial referencia a los ataques cometidos a través de la informática, Madrid, 2001, p. 45, y A. HERNÁNDEZ FERNÁNDEZ, El honor, la intimidad y la imagen como derechos fundamentales, Madrid, 2009, p. 147.

${ }_{4} \mathrm{M}$. CARRILlo, El derecho a no ser molestado (información y vida privada), Navarra, 2003 , p. 45.

5 J. M. Álvarez-Cienfuegos SuÁrez, La defensa de la intimidad de los ciudadanos y la tecnología informática, Navarra, 1999, p. 21. Al respecto se ha sostenido que el tratamiento uni- 
El avance de la tecnología de la información desveló con el paso del tiempo la existencia de nuevos peligros, antes inimaginables, para el derecho a la intimidad. Hoy en día la generalización del uso de la informática permite el entrecruzamiento de datos situados en distintas bases, que por sí mismos tendrían un valor informativo insignificante, pero cuya suma puede llegar a conformar un verdadero perfil del sujeto. De esta forma, la llamada «teoría del mosaico» propició la ampliación del ámbito de actuación del derecho a la intimidad. Esta teoría parte de considerar lo privado y lo público como conceptos relativos en función de quién sea el otro sujeto en la relación informativa. En segundo lugar, esta postura sugiere que existen datos a priori irrelevantes, desde el punto de vista tradicional del derecho a la intimidad, que, en conexión con otros quizás también irrelevantes, pueden servir para hacer totalmente transparente la personalidad de un ciudadano ${ }^{6}$.

En consecuencia, este derecho que se limitaba a la protección de los datos confidenciales o íntimos se amplió para abarcar no sólo los datos que pueden considerarse «privados» o «personales», entre los que se encuentran los datos profesionales, laborales o económico-bancarios, entre otros, sino también los datos «público-relativos». En esta última categoría se integrarían datos personales que el propio titular puede publicitar en determinados momentos y que son accesibles en ciertos registros ${ }^{7}$. Esta nueva configuración del derecho a la intimidad implicaría, por tanto, que

tario que el art. 18.1 CE concede al derecho a la intimidad favorece que este concepto sea interpretado como «vida privada». Cfr. C. RuIz Miguel, La configuración constitucional..., op. cit., p. 78. En opinión de Cabezuelo Arenas: «La intimidad constituye, indiscutiblemente, la realidad más interna del ser humano — más aún que la vida privada, que la engloba o absorbe- y existen vivencias que por su esencia o naturaleza participan de la primera, sin que puedan quedar comprendidas junto a otras de menor trascendencia en la generalidad de lo privado». Vid. A. L. Cabezuelo Arenas, Derecho a la intimidad, Valencia, 1998, p. 36. Sobre este debate vid. también A. I. HerRÁn OrTIZ, El derecho a la intimidad en la nueva Ley..., op. cit., p. 40, y Ó. Alzaga Villaamil, Comentarios a la Constitución Española de 1978, t. II, Madrid, 1996, p. 468.

${ }^{6}$ C. Ruiz Miguel, La configuración constitucional del derecho..., op. cit., p. 78. El autor critica esta teoría al entender que lo privado no puede considerarse relativo, ya que existen aspectos que objetivamente son íntimos o privados y, en consecuencia, merecedores de tutela. En su opinión, la característica de relatividad podría inferirse de lo público, habiendo ciertos datos públicos que pueden tener conectados entre sí una trascendencia para la intimidad. Al respecto vid. también J. De Esteban, P. J. GonzÁlez Trevijano y A. J. SÁnchez Navarro, Tratado de Derecho Constitucional, II, Madrid, 2004, p. 126.

7 Esta categorización surge originariamente de la llamada «teoría de las esferas» y permitía distinguir el grado de protección merecido por los datos de acuerdo a su proximidad con el núcleo del derecho a la intimidad. Al respecto F. Ruiz MARCO, Los delitos contra la intimidad..., op. cit., p. 48. 
este derecho incluya la protección de datos, como el nombre o la dirección profesional, que pueden ser de público conocimiento.

El proceso de expansión que de forma gradual sufre el derecho a la intimidad no se limita a la naturaleza de los datos cuya protección abarca, sino que se extiende a su forma de actuación. De esta manera, el derecho a la intimidad deja de tener un contenido eminentemente negativo para abarcar también un componente positivo, caracterizado por la facultad del sujeto de controlar los propios datos ${ }^{8}$. Ya no se tratará, por tanto, de la libertad de exclusión que faculta al individuo a negar información relativa a las propias experiencias personales, sino de la facultad activa de dominio de la información referida a dichas experiencias o datos personales? ${ }^{9}$.

En este contexto, y una vez alcanzado el convencimiento sobre la conveniencia de reconfigurar el derecho a la intimidad para responder a los retos originados por el desarrollo de nuevas tecnologías, la doctrina comienza a acuñar un nuevo concepto: el llamado «derecho a la autodeterminación informativa». El reconocimiento constitucional de este nuevo derecho se encuadra en el art. 18.4 que sostiene que: «La ley limitará el uso de la informática para garantizar el honor y la intimidad personal y familiar de los ciudadanos y el pleno ejercicio de sus derechos» ${ }^{10}$. El interrogante que surge entonces se centra en la configuración de la autodeterminación informativa como un derecho autónomo o como una manifestación del derecho a la intimidad.

Tras años de discusión sobre el tema, el Tribunal Constitucional pone fin a la cuestión manifestándose abiertamente a favor de la existencia de un nuevo derecho fundamental a la autodeterminación informativa en las Sentencias 290/2000 y 292/2000, ambas de 30 de noviembre ${ }^{11}$. En estas

${ }^{8}$ Así, A. I. Herrán Ortiz, El derecho a la intimidad en la nueva Ley..., op. cit., p. 38, y J. M. Álvarez-Cienfuegos Suárez, La defensa de la intimidad..., op. cit., p. 17.

9 En este sentido A. JAREÑO LEAL, Intimidad e imagen: los límites de la protección penal, Madrid, 2008, p. 16.

${ }^{10}$ La doctrina acepta que si bien la Constitución no reconoce de forma expresa un derecho fundamental a la protección de datos personales, sí contiene un mandato dirigido al legislador en esta materia. De este mandato, por tanto, el Tribunal Constitucional ha deducido la existencia del derecho a la autodeterminación informativa. Cfr. M. AREnAs Ramiro, El derecho fundamental a la protección de datos personales en Europa, Valencia, 2006, p. 439.

${ }^{11}$ Con anterioridad, la Sentencia del Tribunal Constitucional 254/1993 dio un paso fundamental en el reconocimiento del derecho a la autodeterminación informativa. No obstante, este pronunciamiento, que se refería a la incorporación por parte del art. 18.4 CE de una nueva «garantía constitucional», resultaba contradictorio, ya que también señalaba que el derecho fundamental a la intimidad no agotaba su contenido en facultades puramente negativas de exclusión. Al respecto, ampliamente, M. L. SuÁrez Espino, El derecho a la intimidad genética, Madrid, 2008, p. 80. La autora señala que esta Sentencia consoli- 
sentencias, el Tribunal destaca las similitudes y diferencias existentes entre el derecho a la intimidad y el derecho a la autodeterminación informativa, señalando que ambos derechos tienen por objetivo «ofrecer una eficaz protección constitucional de la vida privada personal y familiar». Así, en relación a las diferencias existentes, el Tribunal destaca el carácter eminentemente defensivo del derecho a la intimidad, frente a la naturaleza más activa del derecho a la autodeterminación informativa, el cual atribuye a sus titulares un verdadero control sobre los datos ${ }^{12}$. Por otro lado, el Tribunal también limitará el derecho a la intimidad al ámbito de la esfera privada del individuo, delegando la protección de la totalidad de la información personal al derecho a la autodeterminación informativa ${ }^{13}$.

Se debe concluir, por tanto, que la doctrina del Tribunal Constitucional y el reconocimiento de un nuevo derecho a la autodeterminación informativa implican la reducción del derecho a la intimidad a sus contornos originales, ya que se ha desplazado la vertiente positiva de facultad de control desde el derecho a la intimidad al nuevo derecho a la protección de datos ${ }^{14}$. Así, el derecho a la intimidad será entendido como

da fundamentalmente el derecho a la libertad informática, más que a la autodeterminación informativa, ya que al pertenecer a una etapa más temprana, el legislador se encontraba más preocupado por la incidencia de la informática en los derechos fundamentales que por la facultad de control que debe tener la persona sobre los datos que a él se refieren. Vid. también J. de Esteban, P. J. González Trevijano y A. J. Sánchez Navarro, Tratado..., op. cit., p. 125, y M. Arenas Ramiro, El derecho fundamental a la protección ..., op. cit., p. 447.

12 Para referirse al nuevo derecho la doctrina española ha utilizado distintas denominaciones que en este trabajo se manejarán de forma indistinta. Así, se habla del derecho a la autodeterminación informativa, del derecho a la protección de datos o, incluso, del derecho a la libertad informática.

${ }^{13}$ La doctrina se manifiesta de forma prácticamente unánime a favor de reconocer a la autodeterminación informativa como un derecho autónomo. En este sentido, Serrano Pérez sostiene que concebir la protección de datos como un aspecto de la intimidad podría dificultar su relación con otros derechos fundamentales que ven también peligrar su disfrute ante la amenaza de la informática, de manera que su protección se llevaría a cabo siempre de manera indirecta y por el camino de la intimidad. Cfr. M. M. SERrano Pérez, «El derecho fundamental a la protección de datos. Su contenido esencial», en Nuevas políticas públicas. Anuario multidisciplinar para la modernización de las Administraciones públicas: los derechos fundamentales y las nuevas tecnologías, núm. 1, 2005, p. 250. También en este sentido A. R. GonzÁlez MurúA, «La Agencia de Protección de Datos como instrumento de garantía de los derechos ciudadanos», en Derechos humanos y muevas tecnologías, 2003, p. 154. En opinión de Murillo de la Cueva, se trata de uno de los casos más claros de construcción de un derecho fundamental, ya que en otros supuestos, como la identidad sexual o la salud, se trata de la extensión de la protección derivada de otros derechos. Cfr. P. L. MuRILLO DE LA Cueva, «Avances tecnológicos y derechos fundamentales. Los riesgos del progreso», en Derechos bumanos y nuevas tecnologías, 2003, p. 73.

${ }^{14}$ J. A. Seonne Rodríguez, «De la intimidad genética al derecho a la protección de datos genéticos. La protección iusfundamental de los datos genéticos en el Derecho español 
un derecho de defensa que restringe sus límites a la protección de los datos confidenciales.

\section{La intimidad genética}

A partir de una muestra de ADN puede obtenerse no sólo información que sirva para la identificación de una persona, sino también datos acerca de su actual y futura salud. Consecuentemente, el ADN puede revelar datos que corresponden a la esfera más íntima del sujeto. Así, la intimidad referida a la información genética se situará como una manifestación específica de un genérico derecho a la intimidad personal ${ }^{15}$, junto a la intimidad corporal o la intimidad domiciliaria, entre otras. Se trata del derecho de excluir del conocimiento ajeno los datos que puedan obtenerse a partir del material genético de un individuo.

Este derecho a la intimidad genética tendrá la naturaleza de derecho subjetivo al conferir a su titular la facultad de defenderse de intromisiones no consentidas en su esfera privada, y al mismo tiempo tendrá una naturaleza objetiva, ya que requerirá del Estado la articulación de procedimientos y órganos de control para garantizar y proteger este derecho ${ }^{16}$.

Por otro lado, la caracterización como derecho autónomo de la autodeterminación informativa obliga a considerar, también en relación al mismo, la existencia de una manifestación concreta referida a la información genética. Como sostiene Suárez Espino, el derecho a la intimidad genética desborda el concepto de intimidad en su sentido más clásico, pues no es un simple derecho de defensa frente a injerencias no deseadas, sino más bien un derecho más activo que otorga a su titular un haz de facultades que requieren de él una actitud activa, como los derechos de acceso, rectificación, cancelación, etc. ${ }^{17}$ Así, podrá hablarse de un verdadero babeas genoma, entendido como el derecho que le asiste a un individuo de controlar la información que pueda obtenerse a partir de su $\mathrm{ADN}^{18}$.

(a propósito de las SSTC 290/2000 y 292/2000, de 30 de noviembre)», en Revista de Derecho y Genoma Humano, núm. 16, Bilbao, p. 90. En el mismo sentido M. L. SuÁrez EsPINO, El derecho a la intimidad genética, op. cit., p. 84.

15 C. M. Romeo Casabona y S. Romeo Malanda, Los identificadores del ADN en el sistema de justicia penal, Pamplona, 2010, p. 61.

${ }_{16}$ M. L. SuÁrez EsPino, El derecho a la intimidad genética, op. cit., p. 90.

17 Ibid., p. 89.

${ }^{18}$ Ibid., p. 141. 


\section{BASES DE DATOS DE ADN. TERMINOLOGÍA}

La importancia de la utilización de los análisis de ADN como prueba pericial dentro del proceso penal no ha dejado de incrementarse desde que en 1986 fuera utilizado por primera vez en el Reino Unido para resolver el caso Enderby ${ }^{19}$. La razón de la generalización de su utilización se debe básicamente a dos razones: primero, a la gran fiabilidad que han logrado estas pruebas en los procesos para la identificación de individuos, y segundo, por el desarrollo de nuevos procedimientos que permiten realizar los análisis a partir de muestras muy pequeñas e, incluso, de muestras deterioradas, tratándose de las características que normalmente presentan las muestras de las que se dispone en un proceso judi$\mathrm{cial}^{20}$. Para poder analizar en qué medida el derecho a la intimidad se ve comprometido frente a la utilización de material genético para la investigación criminal será necesario definir previamente, de forma concisa y sin ánimo de exhaustividad, los términos técnicos que serán utilizados en la exposición.

${ }_{19}$ En el caso Enderby se admitieron análisis de ADN como prueba en el proceso y éstos permitieron exonerar de responsabilidad a un joven que sufría un trastorno mental y que había confesado ser el autor de la violación y asesinato de una joven, pudiendo, además, identificarse al verdadero autor del crimen. Ampliamente al respecto J. M. MoRA SÁnCHEZ, Aspectos sustantivos y procesales de la tecnología del ADN. Identificación criminal a través de la buella genética, Bilbao-Granada, 2001.

${ }^{20}$ Nos referimos a los métodos basados en la reacción en cadena de la polimerasa (PCR). La utilización de ADN en la práctica forense se desarrolla a partir de 1984. Por entonces se utilizaba un sistema de sondas multi-locus para el análisis del ADN; no obstante, este método, que aún continúa siendo utilizado para pruebas de paternidad, posee muchas limitaciones para su uso en prácticas forenses. La primera de ellas es la imposibilidad de analizar muestras minúsculas, como pequeñas manchas de sangre, esperma o pelos, que constituyen la mayor parte del trabajo forense. En segundo término, encontramos la imposibilidad de analizar muestras degradadas. El análisis de polimorfismos de ADN mediante la reacción en cadena de la polimerasa solucionó muchos de estos problemas. Por medio de este método pequeños fragmentos de ADN se amplifican in vitro (fuera de un organismo vivo) y a partir de una cadena única se pueden hacer millones de copias, de modo que el producto amplificado se puede analizar fácilmente incluso sin recurrir al uso de sondas. De esta forma se pueden multiplicar, copiar o amplificar artificialmente un trozo o fragmento de ADN todas las veces que sea necesario. Al respecto M. Guillén VÁzQuEZ, C. Pestoni y A. CARRACEDO, «Bases de datos de ADN con fines de investigación criminal: aspectos técnicos y problemas ético-legales», en Revista de Derecho y Genoma Humano, Bilbao, 1998, p. 140; J. M. Mora SÁncheZ, Aspectos sustantivos y procesales..., op. cit., p. 24, y O. García y A. AlONSO, «Las bases de datos de perfiles de ADN como instrumento en la investigación policial», en C. M. Romeo Casabona (ed.), Bases de datos de perfiles de ADN y criminalidad, Bilbao-Granada, 2002, p. 29. 
Las bases de datos de ADN son archivos sistemáticos de datos genéticos o muestras biológicas procedentes de ciertos grupos de población que se emplean con diversos fines. Entre los numerosos ejemplos encontramos las bases de datos de ADN de personas que desarrollan profesiones con riesgo, o bien las bases de datos judiciales-forenses ${ }^{21}$. No obstante, es necesario aclarar la diferencia existente entre las bases de datos genéticos y los archivos de ADN o muestras biológicas, ya que tienen distintas características y naturaleza.

Una base de datos genética contiene «perfiles genéticos», es decir, los resultados de un análisis de ADN. Se trata de números y letras asociados al código de identificación de una persona, incluidos en bases virtuales y cuyo acceso está perfectamente controlado ${ }^{22}$. Como sostiene Lorente Acosta, estos archivos son los únicos que pueden considerarse realmente bases de datos. Por otro lado, los archivos de ADN y los archivos de muestras biológicas no son bases de datos como tales. En el primer caso, nos referimos al almacenamiento de muestras de $\mathrm{ADN}$, normalmente congelado, ya extraído del núcleo celular y de las mitocondrias y dispuesto para ser analizado; mientras que en el supuesto de las muestras biológicas, se trata del archivo de material biológico a partir del cual se puede proceder a extraer ADN para su posterior análisis ${ }^{23}$. En este sentido, es necesario resaltar la importancia de mantener disponibles las muestras biológicas a partir de las cuales se realizan los análisis, en particular por la posible necesidad de llevar a cabo una contrapericia ${ }^{24}$.

Centrándonos en el tema que nos ocupa, las bases de datos con fines de investigación criminal son archivos que contienen perfiles de ADN obtenidos a partir de «muestras de referencia», es decir, a partir de muestras de individuos sospechosos o condenados en una investigación criminal (muestras indubitadas), así como también por perfiles de ADN anónimos

${ }^{21}$ M. BaEta y B. MartíneZ-JarRetA, «Situación actual de las bases de datos de ADN en el ámbito forense: nuevos avances, nuevas necesidades jurídicas», en Revista de Derecho y Genoma Humano, Bilbao, 2009, p. 164.

${ }^{22}$ M. J. ÁldVAReZ Cubero, L. J. Martínez GonzÁlez et al., «Nuevas aplicaciones en identificación genética», en Cuadernos de Medicina Forense, 2010 (1-2), p. 6.

$23 \mathrm{~J}$. A. LoRente Acosta, «Identificación genética: importancia médico-legal de las bases de datos de ADN», en C. M. Romeo CASABONa (ed.), Bases de datos de perfiles de ADN y criminalidad, Bilbao-Granada, 2002, p. 5. También vid. F. González ANDRADE y B. MarTíNEZ JARRETA, Técnicas instrumentales en genética forense, Zaragoza, 2001, p. 20.

${ }_{24}$ También se ha señalado la posibilidad de realizar un intercambio de datos entre diversos países, o bien la necesidad de repetir los análisis para cambiar alguno de los marcadores que se venían utilizando para integrar las bases de datos. Cfr. J. M. Mora SÁnCHEZ, Aspectos sustantivos y procesales..., op. cit., p. 294. 
obtenidos de vestigios biológicos, encontrados en el escenario de un delito, también denominados indicios o muestras dubitadas ${ }^{25}$. El objetivo de estas bases será, por tanto, proceder a la comparación de los datos obtenidos a partir de las muestras de referencia y de los indicios para poder hallar coincidencias e identificar a los autores de los hechos delictivos o bien descartar la culpabilidad de un sujeto.

Resulta especialmente relevante para nuestro estudio identificar qué parte del ADN se analiza y se archiva en las bases de datos. El ADN se divide en ADN codificante y ADN no codificante dependiendo de sus propiedades funcionales. El ADN codificante o expresivo determinará el aspecto general de un organismo concreto, siendo en el caso de los seres humanos el encargado de establecer, entre otros rasgos fenotípicos, el color del pelo, el color de los ojos, etc. Este ADN presenta escasa variabilidad entre los individuos, es decir, es poco polimórfico, razón por la cual carece de interés en las ciencias forenses a fines de la identificación de individuos ${ }^{26}$.

Por otro lado, el ADN no codificante presenta una enorme variabilidad entre los individuos de la población y, por tanto, de su estudio se obtiene información con un gran poder de discriminación ${ }^{27}$. Esta parte del ADN es la determinante de que no haya dos personas que tengan exactamente el mismo código genético, con excepción de los gemelos monovitelinos ${ }^{28}$. Resulta importante remarcar que, en principio, de este $\mathrm{ADN}$ no se puede obtener otro tipo de información paralela o adicional a la meramente identificativa, ya que este ADN carece de información directa o indirecta para la elaboración de elementos de importancia para la vida celular ${ }^{29}$. La identificación personal basada en el ADN se denominó «huella genética», aunque esta terminología cayó en desuso por su inexactitud, ya que no guarda una relación directa con las huellas dactilares ${ }^{30}$. Sobre este particular se realizarán, en su momento, algunas matizaciones.

${ }^{25}$ M. Baeta y B. Martínez-Jarreta, «Situación actual de las bases de datos...», op. cit., p. 164.

${ }^{26}$ J. M. Mora SÁncheZ, Aspectos sustantivos y procesales..., op. cit., p. 19.

27 O. García y A. Alonso, «Las bases de datos de perfiles de ADN...», op. cit., p. 29.

${ }^{28}$ Los gemelos monovitelinos presentan las mismas moléculas de ADN, ya que provienen de la misma fecundación. Cfr. F. Mestres Naval y J. Vives-Rego, «La utilización forense de la huella genética (secuencia del ADN o ácido desoxirribonucleico): aspectos científicos, periciales, procesales, sociales y éticos», en La Ley Penal, núm. 61, junio de 2009 (La Ley 12054/2009).

29 J. M. Mora Sánchez, Aspectos sustantivos y procesales..., op. cit., p. 20.

30 J. Vives-Rego y F. Mestres NAVAL, «Identificación de características forenses avanzadas a partir del ADN: etnogeografía, patología delictiva y morfoanatomía», en La Ley Penal, núm. 91, marzo de 2012 (La Ley 2915/2012). 


\section{LA UTILIZACIÓN DE MUESTRAS DE ADN EN LA PRÁCTICA FORENSE}

En relación a la creación de bases de datos de ADN se aprecia la existencia de tres fases distintas en cada una de las cuales se ven afectados diversos derechos fundamentales. Cada parte del proceso incidirá, además, en el derecho a la intimidad de distinta manera. Así, en un primer momento será necesario valorar en qué medida afectará a la intimidad del sujeto la intervención corporal para la obtención de la muestra de referencia. En una segunda fase, será la realización del análisis genético a partir de la muestra de referencia la que pueda conculcar el derecho a la intimidad. Finalmente, será necesario tener en cuenta cómo deben tratarse los datos obtenidos para que su incorporación a la base de datos no implique la afectación de los derechos fundamentales ${ }^{31}$. Procederemos, por tanto, a analizar estas fases del proceso de forma separada, incidiendo especialmente en los problemas relacionados con la incorporación de los datos en los archivos automatizados, ya que estos constituyen el objeto principal de nuestro trabajo.

\section{La obtención de muestras}

La realización de la prueba pericial a partir de un análisis genético requerirá la toma de muestras en el lugar de comisión del delito; al tratarse de muestras de personas desconocidas éstas se denominarán muestras dubitadas. Estas muestras deberán cotejarse con otras de material genético de los sospechosos o imputados por ese delito. La habilitación legal para la obtención de estas muestras se encuentra en la Ley de Enjuiciamiento Criminal. En efecto, la LO 15/2003, de 25 de noviembre, de modificación del Código Penal en su disposición final primera, modifica múltiples aspectos de la LECrim., entre ellos, la introducción de normas destinadas a regular la prueba de análisis de ADN. De esta forma, el art. 363, párrafo 2. ${ }^{\circ}$, LECrim. sostiene: «Siempre que concurran acreditadas razones que lo justifiquen, el juez de instrucción podrá acordar, en resolución motivada, la obtención de muestras biológicas del sospechoso que resulten indispensa-

${ }^{31}$ En este sentido J. F. ETXEBERRía GuRIDI, «La ausencia de garantías en las bases de datos de ADN en la investigación penal», en Derechos humanos y nuevas tecnologías, 2003, p. 133. 
bles para la determinación de su perfil de ADN. A tal fin, podrá decidir la práctica de aquellos actos de inspección, reconocimiento o intervención corporal que resulten adecuados a los principios de proporcionalidad y razonabilidad» ${ }^{32}$.

Esta normativa ha sido duramente criticada por la doctrina por su parquedad, ya que no expresa todos los presupuestos y las condiciones necesarias para la obtención de las muestras ${ }^{33}$. Así, la Ley de Enjuiciamiento Criminal deja claro que la obtención de muestras biológicas del sospechoso requerirá la concurrencia de una resolución judicial, pero no regula el régimen de sometimiento del sujeto pasivo de las medidas de inspección, registro o intervención, lo que plantea la duda de si es posible la ejecución coactiva de dichas medidas cuando el sujeto se oponga a su práctica ${ }^{34}$.

Posteriormente, la LO 10/2007 en su disposición adicional tercera volverá a incidir en esta cuestión distinguiendo dos situaciones: por un lado, la toma de muestras y fluidos con consentimiento del afectado, que será realizada por la propia policía judicial, sin necesidad del juez de instrucción, y por otro lado, la toma de muestras que requieran inspecciones, reconocimientos o intervenciones corporales, sin consentimiento del afectado, que requerirá, en todo caso, autorización judicial mediante auto motivado ${ }^{35}$. No obstante, esta Ley se referirá de forma exclusiva a la toma de muestras provenientes de personas acusadas de alguno de los delitos incluidos en el art. 3.1.a) de la citada norma. Al respecto, resulta sumamente cuestionable que la LO 10/2007 que regula específicamente el régimen de las bases de datos de ADN no aclare que ocurrirá con los delitos de menor entidad no enumerados en el mencionado apartado. El legislador ha dejado pasar una

32 También en el ámbito del proceso penal abreviado el art. 778.3 LECrim. establece: «El juez podrá acordar, cuando lo considere necesario, que por el médico forense u otro perito se proceda a la obtención de muestras o vestigios cuyo análisis pudiera facilitar la mejor calificación del hecho, acreditándose en las diligencias su remisión al laboratorio correspondiente, que enviará el resultado en el plazo que se le señale».

33 J. MARTín PASTOR, «La recogida por la policía judicial de muestras biológicas para la práctica de la prueba pericial de $\mathrm{ADN}$ en el proceso penal y el régimen de sometimiento del sujeto pasivo de las medidas de inspección, registro o intervención corporal», en La Ley Penal, núm. 89, enero de 2012, p. 3.

34 Sobre esta cuestión, ampliamente, J. A. DEL Olmo, «Las garantías procesales en la identificación de imputados mediante perfiles de ADN», en La Ley Penal, núm. 91, marzo de 2012 (La Ley 2914/2012).

35 Sobre este tema, ampliamente, S. Álvarez Neyra Kapler, La prueba de ADN en el proceso penal, Granada, 2008, p. 41; J. A. DEL Olmo, «Las garantías procesales en la identificación...», op. cit., e I. C. IgLESIAS CANLE, «Análisis crítico de la Ley Orgánica 10/2007, de 8 de octubre, reguladora de la base de datos policial sobre identificadores obtenidos a partir del ADN», en Revista General de Derecho Procesal, núm. 20, 2010, p. 3. 
buena oportunidad para ofrecer al intérprete una ley que regule esta materia de forma omnicomprensiva.

A efectos de nuestro trabajo, en este punto debemos valorar si el acto por el cual se obtiene esa muestra de ADN puede implicar la conculcación del derecho a la intimidad corporal del sospechoso. Así, para poder evaluar la posible afectación de la intimidad corporal, entendida como una manifestación de la intimidad personal, será necesario saber la forma en la que se lleva a cabo esa toma de muestras y qué zonas del cuerpo se verán involucradas. En este sentido, el desarrollo que han experimentado las técnicas para la realización de los análisis de ADN permite, como ya se ha mencionado, realizar las pruebas a partir de muestras biológicas de pequeño tamaño. De esta forma, basta una muestra de saliva para que se pueda proceder al análisis de ADN. Actualmente, la obtención de muestras se realiza a través del denominado frotis bucal, por el cual basta frotar un isótopo por el interior de la boca del acusado para concluir la toma de muestras ${ }^{36}$.

La Sentencia del Tribunal Constitucional 207/1996 sostiene que: «No pueden entenderse como intromisiones forzadas en la intimidad aquellas actuaciones que, por las partes del cuerpo sobre las que operan o por los instrumentos mediante los que se realizan, no constituyen, según un sano criterio, violación del pudor o del recato de la persona» ${ }^{37}$. De esta forma, las intervenciones corporales sólo lesionarán el derecho a la intimidad corporal si se producen en zonas íntimas del cuerpo según un criterio cultural generalizado en la comunidad ${ }^{38}$, lo cual de forma alguna ocurre en el caso

${ }^{36} \mathrm{Al}$ respecto también se plantea la posible afectación al derecho a la integridad física del acusado. Sobre este extremo la STC 207/1996 establece que toda intervención corporal, en tanto implica una lesión o menoscabo del cuerpo, siquiera sea en su apariencia externa, afecta al derecho a la integridad física. De esta forma, las intervenciones corporales podrán ser consideradas leves o graves en razón del grado de sacrificio que acarreen a este derecho. Así, el Tribunal Constitucional considera que la extracción de sangre o de elementos externos del cuerpo como pelos y uñas deberán considerarse como intervenciones leves, mientras que otras intervenciones como punciones lumbares serán consideradas graves. En el caso del frotis bucal, si bien se trata de una intervención corporal destinada a la extracción del cuerpo de elementos para que sean sometidos a informe pericial, se trata de una maniobra que no produce menoscabo físico alguno y, por tanto, entendemos que no es susceptible de afectar el derecho a la integridad corporal. Al respecto J. LÓPEZ BARJA DE QUIROGA, «La prueba en el proceso penal obtenida mediante análisis del ADN», en Cuadernos de Derecho Judicial, VI-2004, Genética y Derecho, p. 218, y S. Álvarez Neyra Kapler, La prueba de ADN..., op. cit., p. 104.

37 Esta Sentencia reitera la doctrina jurisprudencial recogida en la STS 37/1989, de 15 de febrero.

${ }^{38}$ C. M. Romeo Casabona y S. Romeo Malanda, Los identificadores del ADN..., op. cit., p. 59. 
de la obtención de una muestra de saliva ${ }^{39}$. En este sentido, debemos concluir afirmando que la intervención corporal necesaria para obtener una muestra de ADN no afecta al derecho a la intimidad corporal, aunque sí pueda verse afectada, desde una perspectiva más amplia, la intimidad personal, pero no ya por el hecho en sí de la intervención, sino por lo que a través de ésta se pretende averiguar. El tratamiento de esta problemática corresponderá, por tanto, al segundo momento del proceso.

\section{La realización de los análisis genéticos}

Una vez que se cuenta con las muestras biológicas obtenidas en la escena del delito y las correspondientes al acusado debe procederse a la realización de los análisis de ADN. Será en este punto donde entre en juego la posible afectación a la intimidad genética. Deberemos valorar, por tanto, si la realización de estos análisis puede suponer por sí misma la conculcación del derecho a la intimidad personal en su vertiente referida a la información genética.

Como ya se ha explicado, para poder proceder a la identificación de individuos sólo será necesario analizar el ADN no codificante, el cual no contiene información sobre la salud del sujeto ni presente ni futura. En la medida en que estos análisis sólo permitirían obtener datos identificativos del individuo, se ha sostenido que esta problemática no es distinta a la que gira en torno a las huellas dactilares ${ }^{40}$. No obstante, esta afirmación no es exacta. El análisis de ADN no codificante sí aporta ciertos datos que podrían llegar a vulnerar la intimidad del individuo. En este sentido, el análisis del perfil de ADN arroja información sobre la adscripción étnica del individuo, así como sobre su sexo cromosómico, lo que podría revelar alguna anomalía patológica respecto al mismo, así como una adscripción psicológica y social al sexo distinta de la genética ${ }^{41}$. También podrían

39 Sobre la doctrina del Tribunal Constitucional en esta materia, ampliamente, M. JAÉN VALLEJO, «Una visión del problema desde una perspectiva constitucional: el estudio particular de la protección de la intimidad y los bancos genéticos», en Cuadernos de Derecho Judicial, VI-2004, Genética y Derecho, p. 121. Particularmente sobre la jurisprudencia del Tribunal Supremo vid. M. J. Dolz LaGo, «ADN y derechos fundamentales (breves notas sobre la problemática de la toma de muestras de ADN —-frotis bucal— a detenidos e imputados)», en Diario La Ley, núm. 7774, 12 de enero de 2012.

40 M. JaÉn VALLejo, «Una visión del problema desde una...», op. cit., p. 129. También en este sentido M. Guillén Vázquez, C. Pestoni y A. Carracedo, «Bases de datos de ADN con fines de investigación...», op. cit., p. 142.

${ }^{41}$ C. M. Romeo Casabona y S. Romeo Malanda, Los identificadores del ADN..., op. cit., 
obtenerse datos que indiquen que el sujeto es portador del gen que causa el Síndrome de Down o bien una posible infertilidad masculina ${ }^{42}$.

Como señalan Romeo Casabona y Romeo Malanda, sería perfectamente factible que durante un proceso judicial se descubriera incidentalmente la existencia de una relación parental biológica desconocida con anterioridad o, a la inversa, la inexistencia de una relación tenida como tal hasta el momento ${ }^{43}$. Por otro lado, es necesario considerar que, a pesar de que para la realización de la prueba pericial sólo se procederá al análisis del ADN no codificante, la misma muestra biológica de la que se dispone para dicho análisis podría ser utilizada para estudiar partes de ADN codificante. De esta forma, la disponibilidad de muestras biológicas a partir de las cuales se puedan obtener datos sobre la salud del individuo conlleva un riesgo de utilización indebida que en ningún caso podía verificarse mediante las huellas dactilares ${ }^{44}$.

Todas estas consideraciones permiten afirmar la incidencia en la intimidad genética que conlleva la realización de análisis de ADN en la investigación criminal. No obstante, y como es bien sabido, en la medida en que los derechos fundamentales no son derechos absolutos deben soportar limitaciones cuando éstas estén debidamente justificadas.

En este sentido, en la Sentencia 207/1996, el Tribunal Constitucional aclara los requisitos exigibles para que una intervención corporal susceptible de afectar los derechos fundamentales esté justificada, solicitando la concurrencia de los siguientes extremos:

1. Fin constitucionalmente legítimo, pues los derechos pueden ceder ante razones justificadas de interés general convenientemente previstas por la ley, entre las que se encuentra la actuación del ius puniendi.

2. Jurisdiccionalidad, ya que en principio estas actuaciones requerirán una resolución judicial, a excepción de aquellos casos en los que la misma

p. 62. Al respecto, Romeo Casabona también llama la atención sobre la posibilidad de que ciertos datos, por sí mismos irrelevantes, puedan llegar a ser significativos si se ponen en relación con otros datos referidos a sucesos o circunstancias vinculados con aquél, con lo que podría verse afectada la privacidad del sujeto, tal como pone de manifiesto la «teoría del mosaico». Cfr. C. M. Romeo CASABONA, «Utilización de las identificaciones del ADN en la Administración de Justicia», en B. MARTínez JARRETA (dir.), La prueba del ADN en medicina forense. La genética al servicio de la ley en el análisis de indicios criminales y en la investigación biológica de la paternidad, Barcelona, 1999, p. 9.

${ }^{42}$ M. Baeta y B. Martínez-JaRRetA, «Situación actual de las bases...», op. cit., p. 173.

${ }^{43}$ C. M. Romeo Casabona y S. Romeo Malanda, Los identificadores del aDN..., op. cit., p. 62.

${ }^{44}$ Ibid., p. 63. 
Ley autorice a la policía judicial, por acreditadas razones de urgencia y necesidad, a la realización de estas prácticas.

3. Motivación de la resolución judicial que plasme el juicio de ponderación entre el derecho fundamental afectado y el interés constitucionalmente protegido y perseguido.

4. Principio de proporcionalidad, que requerirá, a su vez, satisfacer tres condiciones: el juicio de idoneidad, referido a la capacidad de la medida para cumplir el fin perseguido; el juicio de necesidad, que requerirá que no sea posible hallar otra medida más moderada para la consecución del propósito con igual eficacia, y, finalmente, el juicio de proporcionalidad en sentido estricto, por el cual la medida deberá ser equilibrada por derivarse de ella más beneficios o ventajas para el interés general que perjuicios sobre otros bienes o valores en conflicto.

5. Otras exigencias específicas, por las que la ejecución de las intervenciones corporales deberá efectuarse por personal sanitario y con respeto a la dignidad de la persona.

Trasladando la doctrina del Tribunal Constitucional al caso que nos ocupa, se trata de determinar si la vulneración del derecho a la intimidad genética que conlleva la realización de análisis de ADN en el curso del proceso penal alcanza una justificación constitucional objetiva y razonable. En este sentido, no cabe duda de la legitimidad de la finalidad perseguida, ya que con estas pruebas se busca acreditar la participación misma del acusado en los hechos objeto de la investigación. En relación a la necesidad de una habilitación legal para la realización de las pruebas, como ya se ha indicado, el art. 363, párrafo 2. ${ }^{\circ}$ y la LO 10/2007 (disposición adicional tercera) cubren este requisito, aclarando, incluso, la necesidad de una resolución judicial motivada que autorice la realización de la prueba pericial siempre que no sea posible contar con el consentimiento del acusado.

$\mathrm{El}$ aspecto fundamental y decisivo será, por tanto, el juicio de proporcionalidad de la medida. Al respecto, la fiabilidad que presentan las pruebas de ADN para la identificación de individuos satisfacerá, por sí misma, el juicio de idoneidad requerido, así como también el juicio de necesidad, ya que será posible afirmar en la mayor parte de los casos que el ejercicio mismo del ius puniendi dependerá de la realización de estas pruebas.

En relación al juicio de proporcionalidad en sentido estricto, será necesario determinar si el sacrificio del derecho a la intimidad genética no resulta desmedido en relación a la gravedad de los hechos y a las sospechas existentes. Al respecto, la Ley de Enjuiciamiento Criminal no estable- 
ce ninguna limitación, en la utilización de estas pruebas, relacionada con la entidad del delito investigado y se limita a requerir la «obtención de muestras biológicas del sospechoso», sin aclarar el grado de sospecha necesario para que se proceda a la realización de los análisis ${ }^{45}$.

Por otro lado, si bien la LO 10/2007 (disposición adicional tercera) se refiere a la toma de muestras «para la investigación de los delitos enumerados en la letra a) del apartado 1 del art. $3 »$ de la citada Ley, con lo que parece limitar su utilización frente a delitos de cierta entidad, de la redacción de esta norma no es posible, como ya hemos comentado, excluir la posibilidad de recurrir a las pruebas de ADN en caso de delitos de menor entidad y, en consecuencia, de acuerdo a lo establecido en la Ley de Enjuiciamiento Criminal, la toma de muestras sería posible siempre y cuando el juez así lo determine ${ }^{46}$. Frente a la parquedad de esta regulación, consideramos que la interpretación conjunta de los requisitos exigibles para la realización de los análisis genéticos y la incorporación de sus resultados a los archivos automatizados puede resultar, por tanto, conveniente y esclarecedora.

\section{Incorporación de la información genética a la base de datos de perfiles de ADN}

\section{A. Antecedentes y regulación actual}

Una vez obtenido el perfil genético de un individuo se procederá a su archivo en una base de datos policial de ADN. En este estadio del procedimiento, las posibilidades de injerencia en la intimidad genética del indi-

${ }^{45} \mathrm{La}$ necesidad del cumplimiento de estos requisitos deslegitima la posibilidad de proceder a la realización de análisis de ADN a grupos de la población para poder identificar al responsable de un hecho criminal. Al respecto vid. N. QUAN, «Black and white or red all over? The impropriety of using crime scene DNA to construct racial profiles of suspects», en Southern California Law Review, septiembre de 2001, p. 1403. En este trabajo, la autora relata lo sucedido en el caso del asesino en serie de Baton Rouge, en el que a partir de una muestra de ADN hallada en el lugar del crimen se pudo establecer la adscripción racial del responsable de los hechos como perteneciente en un 85 por 100 a la raza africana y en un 15 por 100 como nativo americano. A partir de este dato se procedió a la realización de análisis de $A D N$ a todo un grupo de población, actuación que permitió, finalmente, localizar al asesino. La autora de este trabajo mantiene una postura crítica en relación con este tipo de procedimientos y se manifiesta en contra de la identificación racial a partir del ADN al considerar que esta prueba carece de certeza. Al respecto, ampliamente, J. Vives-Rego y F. Mestres NAVAL, «Identificación de características forenses avanzadas...», op. cit.

${ }^{46}$ De acuerdo a lo establecido en el art. 778.3 LECrim. Vid. cita núm. 32. 
viduo se acentúan significativamente con la combinación del tratamiento automatizado de los resultados obtenidos ${ }^{47}$. En este proceso se verá involucrado, por tanto, el derecho a la autodeterminación informativa en su vertiente referida a la información genética ${ }^{48}$. Resulta importante remarcar que el derecho a la libertad informática supondrá no sólo el poder del interesado de disposición de los propios datos personales, sino también, y muy especialmente, una prohibición a los poderes públicos y las entidades privadas de convertirse en fuentes de información sin las debidas garantías. A su vez, comportará el deber del Estado de prevenir riesgos que puedan derivarse del acceso o de la divulgación indebida de la información contenidas en los archivos informáticos ${ }^{49}$.

En este ámbito, será la Ley Orgánica 10/2007, de 8 de octubre, reguladora de la base de datos policial sobre identificadores obtenidos a partir del ADN, la que concrete los límites en los que la actuación de los poderes públicos ha de moverse. Será tarea del intérprete analizar si los límites marcados por la Ley respetan el principio de proporcionalidad, lo que permitiría considerar que la injerencia en los derechos fundamentales que esta regulación acarrea pueda ser considerada legítima.

La LO 10/2007 es el resultado de la incorporación a nuestro Derecho positivo de numerosas recomendaciones recibidas por parte de organismos internacionales. Especialmente importante fue el tratamiento que dedicara a esta materia el Consejo de Europa. Así, la Recomendación (92) 1, de 10 de febrero de 1992, del Comité de Ministros, invitaba a los Estados a crear una base de datos o archivo con fines de investigación criminal capaz de servir para el intercambio de datos entre los Estados participantes ${ }^{50}$.

También en el ámbito de la Unión Europea encontramos significativos pronunciamientos sobre este tema. En efecto, las Resoluciones del Consejo núm. 193, de 9 de junio de 1997 (LCEur. 1997, 1866), y de 25 de junio de 2001, inciden en la necesidad de la creación de estos archivos. Posteriormente, el Convenio de Prüm relativo a la profundización de la coope-

${ }^{47}$ F. ETXEBERRía GuRIDI, «La ausencia de garantías en las bases de datos de ADN en la investigación penal», en Derechos humanos y nuevas tecnologías, 2002, p. 118.

${ }^{48}$ Es necesario aclarar que este derecho podrá verse afectado no sólo por la incorporación de muestras indubitadas, esto es, por la incorporación de perfiles genéticos de personas acusadas, sino también por el tratamiento de datos provenientes de muestras dubitadas, en la medida en que se trate de personas identificables.

${ }^{49}$ M. CARRILLO, El derecho a no ser molestado, op. cit., p. 96.

$50 \mathrm{Al}$ respecto vid. L. M. Prieto RamíreZ, «La Ley Orgánica reguladora de la base de datos policial sobre identificadores obtenidos a partir de ADN», en Actualidad Jurídica Aranzadi, núm. 747, Pamplona, 2008. 
ración transfronteriza, en particular en materia de lucha contra el terrorismo, la delincuencia transfronteriza y la migración ilegal, de 27 de mayo de 2005, obliga a los Estados firmantes a crear y mantener ficheros nacionales de análisis de $\mathrm{ADN}$ (art. 2), así como a permitir que las demás partes contratantes tengan acceso a los índices de referencia de sus ficheros de análisis del ADN para los fines de la persecución de delitos (art. 3) ${ }^{51}$. La Unión Europea volverá a prestar atención a esta materia con la aprobación de la Decisión Marco 2008/615/JAI del Consejo, de 23 de junio de 2008, sobre la profundización de la cooperación internacional, en particular en materia de lucha contra el terrorismo y la delincuencia transfronteriza ${ }^{52}$, que incorporará al ordenamiento jurídico de la Unión Europea los elementos básicos de la Convención de Prüm, y con la aprobación de la Decisión Marco 2009/905/JAI del Consejo, de 30 de noviembre de 2009, sobre acreditación de prestadores de servicios forenses que llevan a cabo actividades de laboratorio ${ }^{53}$.

En nuestro país, desde hacía ya varios años la doctrina más autorizada venía poniendo de manifiesto la necesidad impostergable de proceder a regular esta materia ${ }^{54}$. Tras el fallido intento que significó el Borrador de Anteproyecto de Ley reguladora de las Bases de Datos de ADN del año $2000^{55}$, la LO 10/2007 vino a zanjar la cuestión. Según indica la

${ }^{51}$ El Convenio de Prüm fue firmado el 27 de mayo de 2005 por Bélgica, Alemania, España, Francia, Luxemburgo, los Países Bajos y Austria. El instrumento de ratificación de España se publicó en el BOE el 25 de diciembre de 2006 (núm. 307). Ampliamente al respecto vid. E. ZAMBRANO GÓMEZ, «La regulación de los ficheros policiales en España y su tratamiento en la Convención de Prüm. La perspectiva de las autoridades nacionales de protección de datos», en Revista de Derecho Constitucional Europeo, núm. 7, enero-junio de 2007, p. 167; Y. Gómez SÁncheZ, «Los datos genéticos en el Tratado de Prüm», en Revista de Derecho Constitucional Europeo, núm. 7, enero-junio de 2007, p. 137, y J. Ll. Pérez FranCESCH, «Cooperación policial y judicial en la Convención de Prüm», en Revista de Derecho Constitucional Europeo, núm. 7, enero-junio de 2007, p. 119.

52 Esta Decisión Marco se complementa por la Decisión Marco 2008/616/JAI, de 23 de junio de 2008, que pretende establecer las normativas comunes necesarias para la ejecución administrativa y técnica de las formas de cooperación establecidas en la DM 2008/615/JAI.

$53 \mathrm{Al}$ respecto A. M. SAnz Hermida, «Protección de datos en la transmisión transnacional de perfiles de ADN y muestras biológicas a los efectos de la persecución penal», en Revista General de Derecho Procesal, núm. 20, 2010.

${ }^{54}$ Por todos, J. M. Mora SÁncheZ, «Propuestas para la creación y regulación legal en España de una base de datos de $\mathrm{ADN}$ con fines de identificación criminal», en C. M. Romeo Casabona (ed.), Bases de datos de perfiles de ADN y criminalidad, Bilbao-Granada, 2002, p. 57.

${ }_{55}$ Publicado en el Boletín de Información del Ministerio de Justicia, núm. 1867, de 15 de abril de 2000, p. 1536. Sobre el Borrador de Anteproyecto y las anteriores iniciativas para regular esta materia en nuestro país vid., ampliamente, J. M. Mora SÁnCHEZ, «Propues- 
Exposición de Motivos de esta Ley, su objetivo fundamental será «la creación de una base de datos en la que, de manera única, se integren los ficheros de las Fuerzas y Cuerpos de Seguridad del Estado en los que se almacenan los datos identificativos obtenidos a partir de los análisis de $\mathrm{ADN}$ que se hayan realizado en el marco de una investigación criminal, o en los procedimientos de identificación de cadáveres o de averiguación de personas desaparecidas» ${ }^{56}$. De forma congruente con la naturaleza de los derechos que pueden verse afectados, esta Ley reviste - aunque sólo en relación a una parte de su articulado - el carácter de ley orgánica ${ }^{57}$ y se inscribe, según su disposición adicional segunda, en el marco de lo dispuesto por la LO 15/1999 de Protección de Datos de Carácter Personal, la cual resulta de aplicación directa.

\section{B. Infracciones que autorizan la incorporación de los datos en el archivo}

Resulta pertinente en este estadio del trabajo analizar los términos en los que la LO 10/2007 regula la incorporación de perfiles genéticos a la base de datos policial de $\mathrm{ADN}$ haciendo hincapié en aquellos aspectos que pueden comprometer el derecho a la protección de datos personales. Así, el primer elemento a tener en cuenta se refiere a las infracciones punibles que justifican la incorporación de datos de $\mathrm{ADN}$ al fichero policial. $\mathrm{Al}$ respecto, el art. 3 de la LO 10/2007 señala que deberán inscribirse:

«a) Los datos identificativos extraídos a partir del ADN de muestras o fluidos que, en el marco de una investigación criminal, hubieran sido hallados u obtenidos a partir del análisis de las muestras biológicas del sospechoso, detenido o imputado, cuando se trate de delitos graves y, en todo caso, los que afecten a la vida, la libertad, la indemnidad o la libertad

tas para la creación y regulación legal...», op. cit., p. 57. En referencia al Borrador de Anteproyecto del año 2000, una de las cuestiones más criticadas por la doctrina fue su caracterización como una ley ordinaria, ya que esta situación negaba la afectación de derechos fundamentales que implicaba esta regulación. En este sentido E. FERnÁndez García, «La elaboración de bases de datos de perfiles de ADN de delincuentes: aspectos procesales», en C. M. Romeo Casabona (ed.), Bases de datos de perfiles de ADN y criminalidad, Bilbao-Granada, 2002, p. 204.

56 Esta base de datos dependerá del Ministerio del Interior a través de la Secretaría de Estado de Seguridad (art. 1 de la LO 10/2007).

57 Sobre este particular, M. J. Cabezudo Bajo, «Valoración del sistema de protección del dato de ADN en el ámbito europeo», en Revista General de Derecho Europeo, núm. 25, 2011, p. 20. 
sexual, la integridad de las personas, el patrimonio, siempre que fuesen realizados con fuerza en las cosas, o violencia o intimidación en las personas, así como en los casos de la delincuencia organizada, debiendo entenderse incluida, en todo caso, en el término delincuencia organizada, la recogida en el art. 282 bis, apartado 4, de la Ley de Enjuiciamiento Criminal en relación con los delitos enumerados.

b) Los patrones identificativos obtenidos en los procedimientos de identificación de restos cadavéricos o de averiguación de personas desaparecidas.

$[\ldots]$

2. Igualmente, podrán inscribirse los datos identificativos obtenidos a partir del ADN cuando el afectado hubiera prestado expresamente su consentimiento».

Como se ha indicado anteriormente, el derecho a la autodeterminación informativa atribuye a su titular un haz de facultades cuyo ejercicio impone a terceros diversos deberes jurídicos. Entre estas facultades se encuentra el derecho del individuo de que se requiera su previo consentimiento para la incorporación de los datos personales a una base automatizada. En la LO 10/2007 se establece una importante excepción a este derecho, ya que se permite la inscripción de identificadores obtenidos a partir del ADN sin el consentimiento de su titular cuando éstos provengan de acusados de delitos «graves». De esta forma, y de acuerdo al texto de los arts. 13 y 33 del Código Penal, quedarán comprendidos todos los delitos castigados por la Ley con una pena superior a cinco años de prisión ${ }^{58}$. A continuación, la LO 10/2007 señalará determinados grupos de delitos que darán lugar, según el propio texto de la Ley, «en todo caso» a la incorporación de los datos en los archivos. Se tratará de los delitos que afecten a la vida, la libertad, la libertad e indemnidad sexuales o la integridad de las personas.

Esta redacción genera no pocas dudas interpretativas. Así, debemos valorar si resultará exigible también en los casos expresamente menciona-

${ }^{58}$ En este sentido J. F. EtXeberRía Guridi, «La LO 10/2007, de 8 de octubre, reguladora de la base de datos policial sobre identificadores obtenidos a partir del ADN», en Diario La Ley, núm. 6901, Madrid, p. 4. Sobre la interpretación de este precepto no existe consenso. Así, Martín Pastor considera que «delito grave» debe ser considerado aquel que lleve aparejada una pena de prisión de más de nueve años, pues será enjuiciado por el cauce del proceso penal ordinario. Cfr. J. MARTín PASTOR, «Avances jurisprudenciales y legislativos sobre la prueba pericial de ADN en el proceso penal. En especial, la base de datos policial sobre identificadores obtenidos a partir del ADN creada por Ley Orgánica 10/2007, de 25 de noviembre», en C. SAlCEDo Beltrán (coord.), Investigación genética y Derecho, Valencia, 2008, p. 73. 
dos el requisito de la gravedad, o bien si la comisión de cualquier hecho delictivo comprendido dentro de estos grupos puede dar lugar sin más exigencias a la inscripción de los datos. En opinión de Exteberría Guridi, habrá que hacer compatibles ambos criterios y exigir que también en el caso de los tipos penales mencionados concurra el requisito de la gravedad. Este autor apoya su decisión en el mismo texto de la Exposición de Motivos de la LO 10/2007, que resalta la conveniencia de la inscripción de datos provenientes de imputados y sospechosos de «determinados delitos de especial gravedad y repercusión social» ${ }^{59}$. Es indudable que esta interpretación lleva a resultados que, en la mayor parte de los supuestos, resultan satisfactorios. A pesar de ello, debemos manifestarnos en contra de esta opción. En nuestra opinión, el texto de la Ley resulta sumamente claro al indicar que en relación a los delitos mencionados «en todo caso» se podrá proceder a la incorporación de los datos aun sin el consentimiento del titular de los mismos. Por ello, consideramos que exigir para todos los grupos de delitos el requisito de gravedad supone una interpretación forzada e, incluso, contraria al texto de la Ley.

En referencia a la decisión del legislador, y a pesar de tener en cuenta la indiscutible relevancia de los bienes jurídicos escogidos, no se alcanza a comprender por qué se decide abandonar en estos supuestos el criterio de la gravedad de las infracciones. Así, si analizamos en particular el caso de los delitos contra la libertad, comprobamos que, de acuerdo al texto de la Ley, será posible proceder al almacenamiento de perfiles genéticos obtenidos de personas acusadas de un delito de amenazas simples, castigado en el art. 169.2 CP con una pena de seis meses a dos años de prisión, o bien de un delito de amenazas condicionales castigado en el art. 171 CP con una pena de prisión de tres meses a un año o multa de seis a veinticuatro meses. La situación se repite en referencia al delito de coacciones, que el art. 172 castiga con una pena de prisión de seis meses a tres años o multa de doce a veinticuatro meses. En este sentido, debemos considerar que la incidencia en los derechos fundamentales que produce la incorporación de datos procedentes de acusados de delitos de amenazas o coacciones resulta totalmente desproporcionada. Si el legislador hubiera decidido mantener el criterio de la gravedad del delito también en referencia a los delitos

59 J. F. ETXEBERRÍA GURIDI, «La LO 10/2007, de 8 de octubre, reguladora...», op. cit., p. 5. A favor, M. DE Hoyos SANCHO, «Obtención y archivo de identificadores extraídos a partir del ADN de sospechosos: análisis de la regulación española a la luz de la jurisprudencia del Tribunal Europeo de Derechos Humanos», en Revista de Derecho Comunitario Europeo, núm. 35, enero-abril de 2010, Madrid, p. 102. 
contra la libertad, se procedería únicamente a la inscripción de los datos provenientes de delitos de detenciones ilegales (pena de prisión de cuatro a seis años, art. $163 \mathrm{CP}$ ) y secuestros (pena de prisión de seis a diez años, art. $164 \mathrm{CP}$ ), que sí están incluidos dentro de la categoría de «delitos graves» y que son aquellos que, en el ámbito de los delitos contra la libertad, pueden legitimar realmente una medida de estas características.

Situación similar se produce en relación a los delitos contra la libertad e indemnidad sexuales, donde quedarían incluidos delitos tales como el acoso sexual, cuya pena no supera los cinco meses de prisión (art. 184 $\mathrm{CP}$ ), o la posesión para uso propio de material pornográfico en cuya elaboración se hubiera utilizado a menores de edad o incapaces, donde la pena se eleva de tres meses a un año de prisión o multa de seis meses a dos años (art. 189. 2 CP).

En relación a los delitos que afectan al patrimonio, el legislador exige que se trate de delitos realizados con «fuerza en las cosas o violencia o intimidación en las personas». En este ámbito, entendemos que el criterio utilizado para definir las infracciones que quedan comprendidas sí resulta adecuado, ya que la utilización de fuerza en las cosas o violencia e intimidación en las personas revela indudablemente una mayor peligrosidad en el sujeto responsable de la infracción penal. Así, si mantuviéramos la interpretación que exige necesariamente la inclusión de la infracción en la categoría de delitos graves, deberíamos excluir al delito de robo con fuerza en las cosas, tipo básico, de esta enumeración, ya que la pena prevista para esta infracción es de uno a tres años (art. $240 \mathrm{CP})^{60}$, opción que no parece adecuada por la facilidad que sí puede suponer en estos casos la utilización de análisis de ADN para la investigación de estos delitos ${ }^{61}$.

Consecuentemente, entendemos que hubiera resultado preferible que el legislador hubiera recurrido al método de la enumeración y hubiera señalado de forma directa los hechos delictivos con relevancia suficiente para quedar incluidos en el art. 3 de la LO 10/2007. Por otro lado, el método escogido permite que queden incluidos hechos que por su escasa relevancia determinan la falta de proporcionalidad de la medida. Los

${ }^{60}$ En este sentido J. F. EtXeberRía GURIDI, «La LO 10/2007, de 8 de octubre, reguladora...», op. cit., p. 5.

${ }^{61} \mathrm{La}$ lista de excepciones se completa con una referencia a los casos de delincuencia organizada, remitiendo expresamente el legislador a las previsiones del art. 282 bis, apartado 4, de la Ley de Enjuiciamiento Criminal. Esta norma realiza una larga enumeración de delitos en algunos de los cuales no se alcanza a comprender la utilidad del recurso a las pruebas genéticas, tal como ocurre en el caso de los delitos contra los derechos de los trabajadores o los delitos relativos a la propiedad intelectual. 
problemas interpretativos se incrementan si consideramos que el legislador se refiere a los delitos contra «la integridad de las personas». No existe en el Código Penal ningún capítulo dedicado a regular, sin más, los delitos contra la integridad de las personas. Podríamos entender, por tanto, que el legislador se refiere a los delitos encargados de proteger la integridad física, esto es, los delitos de lesiones. No obstante, este precepto también podría hacer alusión a los delitos contra la integridad moral. Resulta, por tanto, imprescindible una aclaración de estos extremos ${ }^{62}$.

Otros países de nuestro entorno han utilizado distintos criterios para limitar los datos que pueden inscribirse en las bases policiales. En el caso de Alemania, el parágrafo 8g StPO exige, además de tratarse de hechos delictivos de cierta trascendencia, la concurrencia de un fundamento que permita considerar, teniendo en cuenta la modalidad del hecho o su ejecución, o por la personalidad del inculpado, o por otros motivos conocidos, la existencia de un nivel razonable de probabilidad de que en el futuro se proceda a incoar otro proceso penal contra el inculpado, es decir, se requiere que se trate de delincuentes con cierto peligro de reincidencia. Al respecto, no creemos que la incorporación de una previsión de estas características en la legislación española pueda resultar positiva. Por otro lado, entendemos que la posibilidad de que un sujeto vuelva a cometer hechos delictivos de similar naturaleza es un elemento incierto y de naturaleza subjetiva que sólo puede complicar el manejo de la base de datos policial.

En este orden de cosas, resulta especialmente interesante atender a la previsiones de la Recomendación del Consejo de Europa (92) 1. Esta Recomendación prescinde de cualquier limitación relacionada con las características del hecho delictivo a la hora de permitir el recurso a los análisis de ADN como prueba pericial en el proceso penal, ya que, según se aclara en su memoria explicativa, se pretende que estas medidas puedan ser utilizadas como vía de absolución de la persona acusada por un delito. Desde esta perspectiva resulta conveniente, por tanto, la generalización de la utilización de este medio probatorio. No obstante, a la hora de permitir la incorporación de los datos a los archivos automatizados, la Recomendación establece la condición de que se trate de muestras obtenidas a par-

${ }^{62}$ Sobre este particular Exteverría Guridi también se plantea la indefinición relativa a los delitos contra la vida, preguntándose si quedarán comprendidos solamente los delitos contra la vida humana independiente o también los delitos contra la vida humana dependiente. Cfr. J. F. EtxeberRía GuRidi, «La LO 10/2007, de 8 de octubre, reguladora...», op. cit., p. 5. 
tir de infracciones graves contra la vida, la integridad y la seguridad de las personas, en virtud de la posible afectación al derecho a la protección de datos que esta inscripción puede ocasionar.

Siguiendo el criterio de la Recomendación del Consejo de Europa (92) 1 es posible aceptar la conveniencia de la utilización de este medio probatorio como elemento de exculpación y sostener la proporcionalidad de la medida aun cuando se trate de delitos de menor entidad. En el mismo sentido, es posible llegar a la conclusión de que las previsiones de la Ley de Enjuiciamiento Criminal relativas a la utilización del ADN como prueba pericial en un proceso criminal, aun cuando no limitan su utilización a los delitos graves, satisfacen en cualquier caso el juicio de proporcionalidad. No obstante, no puede trasladarse esta misma conclusión al ámbito de las bases de datos automatizadas. En esta materia el hecho de que se haya procedido a realizar una enumeración tan amplia nos lleva a pensar que el legislador no ha valorado adecuadamente la injerencia en los derechos fundamentales que la incorporación de estos datos puede suponer.

El art. 4 de la LO 10/2007 establece que «sólo podrán inscribirse en la base de datos policial regulada en esta Ley los identificadores obtenidos a partir del ADN, en el marco de una investigación criminal, que proporcionen, exclusivamente, información genética reveladora de la identidad de la persona y de su sexo». De esta forma, el legislador, sin utilizar expresamente esta terminología, establece que sólo se podrán inscribir los resultados de los análisis realizados sobre partes no codificantes del ADN. A pesar de estas precauciones, como ya se ha explicado, ello no implica que de este ADN no pueda obtenerse información que pueda vulnerar el derecho a la intimidad genética del individuo ${ }^{63}$. También en esta línea, la doctrina ha aceptado que, a pesar de que los perfiles genéticos no deben expresar, en principio, información sobre la salud del individuo, ni presente ni futura, esta información sea considerada como «datos de salud» y reciba, por tanto, el tratamiento reservado a los «datos sensibles», siendo este criterio también asumido por la Exposición de Motivos de la LO 10/2007 ${ }^{64}$.

${ }^{63}$ Vid. cita núm. 41.

${ }^{64} \mathrm{La}$ LOPDP, en su art. 7, reconoce tres grupos de datos especialmente protegidos: los datos que revelan la ideología, la afiliación sindical, religión y creencias; los datos relativos a la salud, origen racial y vida sexual, y, finalmente, los datos de carácter personal relativos a la comisión de infracciones penales o administrativas. Estos tres grupos están regulados según un régimen específico, recibiendo los datos relativos a la salud las mayores garantías. Por otro lado, los datos genéticos no son mencionados en la LOPDP. La falta de una regulación expresa sobre los datos genéticos llevó a la doctrina a entender que debían ser considerados como «datos de la salud». En el caso de los análisis genéticos en sentido estricto, es decir, 
Además, no es posible olvidar que la realización de estas pruebas y el almacenamiento de estos datos suponen necesariamente el archivo de muestras biológicas sobre las que podrían realizarse análisis de ADN codificante. Todo ello lleva a reiterar la conveniencia de proceder a un análisis más exhaustivo que permita determinar qué infracciones revisten gravedad suficiente como para justificar la proporcionalidad de la medida a los fines perseguidos.

\section{Grado de implicación del acusado por el delito}

Tal como establece la Ley 10/2007, se procederá a la inscripción del perfil genético del «sospechoso, detenido o imputado». Esta redacción genera numerosos interrogantes, especialmente en relación a qué debemos entender por «sospechoso». La Ley de Enjuiciamiento Criminal también utiliza esta expresión en el art. 363 para indicar qué individuos deberán someterse a la prueba pericial, pero sin aclarar tampoco el alcance de este término. No obstante, en este ámbito, la exigencia de una resolución judicial motivada que exprese la necesidad de la realización de la prueba y la exigencia del art. 363, párrafo $2 .^{\circ}$, de la existencia de «acreditadas razones», satisfacen las exigencias propias del principio de proporcionalidad, teniendo en cuenta, además, que estas pruebas pueden servir como elemento de exculpación del individuo ${ }^{65}$.

No obstante, en relación a la incorporación de los datos en un fichero automatizado, la condición de «sospechoso» no se presenta como un indicio de criminalidad suficiente como para satisfacer las exigencias del juicio de proporcionalidad al que han de responder las diligencias restrictivas

del ADN codificante, debía aceptarse sin objeciones que los datos que se obtienen deben ser considerados como datos de la salud, ya que éstos proporcionan información sobre la salud del individuo presente y futura. Así, a pesar de que esta afirmación es más dudosa en el caso de los perfiles de ADN, también en este caso la doctrina consideró de forma mayoritaria que esta información debía quedar comprendida en el concepto de «dato de la salud». También en este sentido, la Recomendación (97) núm. 5 del Consejo de Europa considera incluidos los datos genéticos dentro de la definición de datos relativo a la salud en sentido amplio o dato médico. A favor de esta postura C. M. Romeo CASABONA, «Utilización de las identificaciones del ADN...», op. cit., p. 9, y A. A. GUERRERO MORENO, «La regulación de los datos genéticos y las bases de datos de ADN», en Criterio Jurídico, vol. 8, núm. 2, Santiago de Cali, 2008, p. 223. Contra esta opinión Y. GÓmEZ SÁNCHEZ, «Los datos genéticos...», op. cit., p. 14. Finalmente, la Exposición de Motivos de la LO 10/2007 reconoce expresamente el carácter sensible de los datos relacionados con el ADN poniendo fin a la diferencia de opiniones.

${ }^{65}$ J. López Barja de Quiroga, «La prueba en el proceso penal...», op. cit., p. 225. 
de derechos fundamentales. De acuerdo al texto de la Ley 10/2007, el perfil genético que se obtenga como resultado del análisis de $\mathrm{ADN}$ realizado a un sospechoso podría pasar a integrar, sin más, la base de datos policial. Ello nos lleva a comprobar que en caso de que durante la tramitación del proceso se llegara al convencimiento de la inocencia del sospechoso, antes, incluso, de la imputación formal del delito, estos perfiles podrían pasar a integrar, de todas formas, la base de datos policial. Entonces, ¿podrán incorporarse en estos archivos datos que pertenezcan a cualquier persona sobre las que hayan recaído sospechas en un momento inicial de la investigación, con independencia de que se haya esclarecido el suceso evidenciando el carácter erróneo de las iniciales sospechas? Esta situación es, además, especialmente grave si tenemos en cuenta que corresponde a la policía judicial y no al juez la decisión sobre la inscripción de los perfiles de $\mathrm{ADN}^{66}$.

Estas circunstancias revelan que no es posible conformarse con el juicio provisional existente en el momento de acordar la medida pericial para proceder a la inscripción de los perfiles genéticos. Por ello, frente a la opción de incorporar los datos en un momento inicial del proceso, parece preferible la consistente en condicionar el almacenamiento de los datos a que recaiga una decisión definitiva acerca de la participación de esa persona en el hecho penal. Mientras que la primera opción es más eficaz en relación a la finalidad perseguida por el fichero, la segunda presenta más garantías desde el punto de vista de los derechos a la protección de los datos personales del afectado ${ }^{67}$.

${ }^{66} \mathrm{Al}$ respecto, Romeo Casabona y Romeo Malanda se plantean la posibilidad de que un acto de investigación por un delito sea iniciado unilateralmente por los miembros competentes de la policía judicial, ya que esta situación podría suponer, sin más, que un sujeto adquiriera la condición de sospechoso. De esta forma se generaría el presupuesto formal requerido para ser inscrito en la base de datos policial con el riesgo de que esta medida, además de unilateral, pueda ser arbitraria al poder sustraerse fácilmente de cualquier fiscalización. Cfr. C. M. Romeo Casabona y S. Romeo Malanda, Los identificadores del ADN..., op. cit., p. 190. A favor de que los tests genéticos en sus distintas fases de recogida de muestras, análisis de los mismos, registro de los resultados y destrucción de los mismos estén en todo caso presididos por la actuación judicial, P. J. CUESTA PASTOR, «Los mecanismos de identificación y su uso en el proceso penal: interrogantes a propósito de la "Huella de ADN"», en C. M. Romeo Casabona (ed.), Bases de datos de perfiles de ADN y criminalidad, Bilbao-Granada, 2002, p. 124.

${ }^{67}$ F. EtXeberRía Guridi, «La ausencia de garantías...», op. cit., p. 137. 


\section{La cancelación de los datos}

El problema de la incorporación de los perfiles genéticos de sospechosos en la base de datos policial se ve agravado por los plazos estipulados para la cancelación de los mismos. El art. 9. 1 de la LO 10/2007 establece lo siguiente:

«1. La conservación de los identificadores obtenidos a partir del ADN en la base de datos objeto de esta Ley no superará:

El tiempo señalado en la Ley para la prescripción del delito.

El tiempo señalado en la Ley para la cancelación de antecedentes penales, si se hubiese dictado sentencia condenatoria firme, o absolutoria por la concurrencia de causas eximentes por falta de imputabilidad o culpabilidad, salvo resolución judicial en contrario.

En todo caso, se procederá a su cancelación cuando se hubiese dictado auto de sobreseimiento libre o sentencia absolutoria por causas distintas de las mencionadas en el epígrafe anterior, una vez que sean firmes dichas resoluciones. En el caso de sospechosos no imputados, la cancelación de los identificadores inscritos se producirá trascurrido el tiempo señalado en la Ley para la prescripción del delito.

En los supuestos en que en la base de datos existiesen diversas inscripciones de una misma persona correspondientes a diversos delitos, los datos y patrones identificativos inscritos se mantendrán hasta que finalice el plazo de cancelación más amplio».

De esta forma, si una persona es imputada por un hecho delictivo se procederá a la cancelación de los datos si se ha dictado un auto de sobreseimiento libre o una sentencia absolutoria, salvo que la misma esté motivada en la concurrencia de causas eximentes por falta de imputabilidad o culpabilidad. Por otro lado, en caso de que el sujeto sea condenado, la cancelación se producirá cuando se proceda a la cancelación de los antecedentes penales. El art. 136.2.2. ${ }^{a}$ del Código Penal establece que, en caso de delitos graves, para que se proceda a la cancelación de los antecedentes penales deberá trascurrir, sin delinquir de nuevo el culpable, un plazo de cinco años. No obstante, si se trata de sujetos que hayan sido considerados sospechosos durante la investigación sin llegar a existir indicios suficientes de culpabilidad como para proceder a la imputación, será necesario esperar a que trascurra el plazo de prescripción del delito para poder reclamar la cancelación de los datos. Al respecto, es necesario recordar que el tiem- 
po señalado por la Ley para la prescripción de un delito de homicidio es de veinte años. Esto nos lleva a que los datos de una persona condenada por un delito de homicidio que haya cumplido una pena, por ejemplo, de diez años, serán cancelados al trascurrir un plazo de quince años, mientras que el sujeto sospechoso deberá esperar veinte años para que se proceda a la cancelación de estos datos. Se trata, por tanto, de una regulación que pone al sospechoso de un hecho delictivo en peor lugar que a una persona condenada por ese mismo delito.

Sobre esta cuestión resulta relevante el pronunciamiento del Tribunal Europeo de Derechos Humanos en el caso S. y Marper contra el Reino Unido, de 4 de diciembre de $2008^{68}$. En este caso se juzgaba la actuación de la policía frente a los siguientes hechos: en el año 2001, S., con once años de edad, es detenido e inculpado de robo con violencia en grado de tentativa, siendo absuelto pocos meses después. En el mismo año, Marper es detenido por un delito de acoso a su compañera, archivándose definitivamente la causa antes de que tuviera lugar la comparecencia previa al proceso, ya que la denuncia fue retirada por su compañera con la que el acusado se había reconciliado. En ambos casos, la policía procedió a la toma de las huellas dactilares y muestras de ADN, negándose, pese a los sucesivos reclamos de los interesados, a proceder a su eliminación.

En su Sentencia, el TEDH concluye que la conservación tanto de muestras celulares como de los perfiles de ADN, por la información que puede obtenerse a partir de su tratamiento, constituye un atentado contra el derecho a la vida privada en el sentido del art. 8. 1 del Convenio Europeo para la Protección de los Derechos Humanos y Libertades Fundamentales $(\mathrm{CEDH})^{69}$. En opinión del Tribunal, el carácter general e indiferenciado del poder de conservación de los datos genéticos de personas sospechosas pero no condenadas refleja un desequilibrio entre los intereses públicos y privados en juego y determina, por tanto, que se trate de una lesión desproporcionada del derecho de los reclamantes al respeto

68 S. and Marper v. The United Kingdom (demandas núm. 30562/04 y 30566/04). Al respecto, ampliamente, G. GonZÁLEZ Fuster, «TEDH, Sentencia de 4 de diciembre de 2008, S. y Marper c. Reino Unido, 30562/04 y 30566/04, art. 8 CEDH. Vida privada. Injerencia en una sociedad democrática. Los límites del tratamiento de datos biométricos de personas no condenadas», en Revista de Derecho Comunitario Europeo, núm. 33, Madrid, 2009, p. 619, y M. DE Hoyos SANCHO, «Obtención y archivo de identificadores...», op. cit., p. 93.

69 Convenio Europeo para la Protección de los Derechos Humanos y Libertades Fundamentales de 4 de noviembre de 1950, incorporado al ordenamiento español mediante el Instrumento de Ratificación de 26 de septiembre de 1979 (BOE, núm. 243, de 10 de octubre de 1979). 
de su vida privada, no pudiendo afirmarse su necesidad en una sociedad democrática ${ }^{70}$. El Tribunal, además, llama la atención sobre el preocupante riesgo de estigmatización derivado del hecho de que personas no reconocidas culpables de ninguna infracción y que gozan, por tanto, del derecho a la presunción de inocencia, sean tratados de la misma manera que personas condenadas.

Es necesario aclarar que la legislación del Reino Unido permite la incorporación a la bases de datos de los perfiles genéticos de todas las personas que hayan sido sospechosos, advertidos o condenados de un hecho delictivo, independientemente de la gravedad de la infracción y sin límite tempo$\mathrm{ral}^{71}$. La regulación que incorpora a nuestro Derecho la Ley 10/2007 dista mucho de estos extremos. No obstante, sí sería necesario realizar algunas modificaciones para impedir que en determinados casos la inscripción y/o mantenimiento de la información en la base de datos pueda ser considerada una medida desproporcionada con respecto a los fines perseguidos ${ }^{72}$. En este sentido, compartimos la opinión de De Hoyos Sancho cuando sostiene que si en la causa abierta no se llegaran a recabar los elementos suficientes para poder imputar al sujeto sospechoso de uno de los delitos referidos en el art. 3 de la Ley, los datos deberían cancelarse «cuanto antes» del fichero policial y no esperar, de ninguna forma, a que se cumpla el plazo de prescripción del delito ${ }^{73}$.

\section{E. El archivo de muestras biológicas}

Las previsiones de la LO 10/2007 también resultan insuficientes en relación con las condiciones para el archivo de las muestras biológicas. Al respecto, la Ley sólo establece en el art. 5.1: «Las muestras o vestigios tomados respecto de los que deban realizarse análisis biológicos se

70 Según señala el TEDH en la Sentencia S. y Marper c. Reino Unido, para que una injerencia en el derecho a la vida privada de los individuos esté justificada deberán concurrir los siguientes requisitos: a) previsión legal, b) finalidad legítima, c) necesidad en una sociedad democrática para la consecución de la finalidad legítima que se persigue, lo que da lugar a la aplicación del principio de proporcionalidad.

${ }^{71}$ De acuerdo a la Circular del Ministerio de Interior inglés de 1995. Al respecto J. A. LoRente Acosta, «Identificación genética...», op. cit., p. 15, y J. M. MORA SÁNCHEZ, Aspectos sustantivos y procesales..., op. cit., p. 304.

72 «Cualquier exceso temporal, incluso mínimo, calificaría a la medida de desproporcionada». Cfr. M. DE Hoyos SANCHO, «Obtención y archivo de identificadores...», op. cit., p. 114.

${ }_{73}$ M. DE Hoyos SANCHO, «Obtención y archivo de identificadores...», op. cit., p. 111. 
remitirán a los laboratorios debidamente acreditados. Corresponderá a la autoridad judicial pronunciarse sobre la ulterior conservación de dichas muestras o vestigios». Sobre este particular no existe, por tanto, en la Ley ninguna referencia sobre el límite temporal máximo para el mantenimiento de las muestras. El silencio del legislador sobre esta cuestión resulta sumamente cuestionable, ya que se trata de un asunto de gran importancia. Si los perfiles de ADN, como resultado de análisis de ADN no codificante, sólo pueden aportar información identificativa de una persona, las muestras biológicas son susceptibles de ser utilizadas para la realización de análisis de ADN codificante que aporte una amplia información relativa a la salud del individuo ${ }^{74}$.

Sobre este particular, una parte de la doctrina ha puesto en duda el peligro que puede significar el mantenimiento en los archivos de estas muestras. En este sentido, se ha indicado que en la mayor parte de los casos no se trataría de muestras aptas para la realización de análisis clínicos debido a la escasez del material y por las condiciones y características del mismo, ya que se guarda en forma de manchas secas, con lo cual la calidad del ADN se vería afectada a medio y largo plazo ${ }^{75}$. No obstante, no es posible dejar de considerar que, tal como sostiene Fernández García, el hecho de que en la actualidad se pueda catalogar el 80 por 100 del ADN como «no codificante» deriva más de lo inconcluso de las investigaciones científicas que del hecho de que este ADN no tenga ninguna otra función que la meramente identificativa, por lo que es muy probable que en el futuro las regiones de ADN no codificantes puedan aportar información sobre la salud del individuo, multiplicando, por tanto, el peligro de la conservación de estas muestras ${ }^{76}$. En esta medida, entendemos que el almacenamiento de muestras biológicas requiere de una minuciosa regulación que, como se ha indicado, no se encuentra en la LO 10/2007.

${ }^{74}$ En este sentido C. M. Romeo Casabona y S. Romeo Malanda, Los identificadores del ADN..., op. cit., p. 63.

75 M. Lorente Acosta, J. A. Lorente Acosta y E. Villanueva Cañadas, «Identificación humana y medicina legal: consideraciones éticas y jurídicas», en M. B. MARTínez JARRETA, $L a$ prueba del ADN en medicina legal, Barcelona, 1999, p. 28.

${ }^{76}$ E. Fernández García, «La elaboración de bases de datos de perfiles...», op. cit., p. 139. También vid. S. Álvarez NeYRA KAPLer, La prueba de ADN..., op. cit., p. 114. 


\section{CONCLUSIONES}

Tanto la Ley de Enjuiciamiento Criminal, en relación a la realización de análisis genéticos como prueba pericial en el proceso penal, como la LO 10/2007, referida a la incorporación de los datos obtenidos en archivos automatizados, presentan significativas carencias en asuntos de especial importancia. Si bien algunas de estas lagunas pueden ser solventadas a partir de la interpretación jurisprudencial y doctrinal, hay otros casos en los que se requiere una reforma que dé una respuesta satisfactoria a este problema.

En este sentido, resultan insuficientes las previsiones legislativas acerca de las infracciones que pueden dar lugar a la realización de los análisis, así como a la incorporación de los resultados en la base de datos. En relación a esta última cuestión, el legislador, con el objetivo de beneficiar la investigación de delitos que afectan a bienes jurídicos especialmente relevantes y cuya comisión puede generar gran alarma social, amplía de forma excesiva el ámbito de los comportamientos ilícitos que autorizan la incorporación de los datos genéticos en un archivo policial, incluyendo delitos de menor gravedad cuyo injusto no presenta la entidad suficiente como para justificar la proporcionalidad de la medida. Tampoco puede darse por válido sin más el requisito de la condición de «sospechoso», pues su indefinición puede conducir a resultados poco deseables, especialmente porque puede provocar que personas que gozan aún del beneficio de la presunción de inocencia sean puestas en peor situación que sujetos condenados.

Para concluir, es necesario destacar la necesidad de profundizar en la regulación de las condiciones del mantenimiento de muestras biológicas para poder disminuir el peligro de utilización indebida que necesariamente el archivo de las mismas acarrea. En la medida en que se trata de actuaciones que indudablemente afectan tanto a la intimidad personal, en su vertiente referida a la información genética, como al derecho a la autodeterminación informativa, resulta fundamental proceder a su esclarecimiento, evitando así que puedan ser consideradas ilegítimas por no satisfacer las exigencias de la proporcionalidad.

Resulta imprescindible que seamos conscientes de que los nuevos descubrimientos en el terreno de la investigación científica, unidos al vertiginoso avance de la informática, requieren de una legislación que esté caracterizada por su precisión y que deje el menor margen posible 
a la interpretación, pues se trata de un ámbito especialmente proclive a la afectación del derecho a la intimidad. Si no somos extremadamente cautelosos en esta materia, la información genética puede convertirse en un futuro no muy lejano en un arma de doble filo, siendo utilizada como elemento de discriminación al servicio de intereses particulares de diversa índole. 